\title{
The cultural context of patient's autonomy and doctor's duty: passive euthanasia and advance directives in Germany and Israel
}

\author{
Silke Schicktanz $\cdot$ Aviad Raz $\cdot$ Carmel Shalev
}

Published online: 31 July 2010

(c) The Author(s) 2010. This article is published with open access at Springerlink.com

\begin{abstract}
The moral discourse surrounding end-of-life (EoL) decisions is highly complex, and a comparison of Germany and Israel can highlight the impact of cultural factors. The comparison shows interesting differences in how patient's autonomy and doctor's duties are morally and legally related to each other with respect to the withholding and withdrawing of medical treatment in EoL situations. Taking the statements of two national expert ethics committees on EoL in Israel and Germany (and their legal outcome) as an example of this discourse, we describe the similarity of their recommendations and then focus on the differences, including the balancing of ethical principles, what is identified as a problem, what social role professionals play, and the influence of history and religion. The comparison seems to show that Israel is more restrictive in relation to Germany, in contrast with previous bioethical studies in the context of the moral and legal discourse regarding the beginning of life, in which Germany was characterized as far more restrictive. We reflect on the ambivalence of the cultural reasons for this difference and its expression in various dissenting views on passive
\end{abstract}

S. Schicktanz $(\bowtie)$

Department of Medical Ethics and History of Medicine, University Medical Center Göttingen, Göttingen, Germany

e-mail: silke.schicktanz@medizin.uni-goettingen.de

A. Raz

Department of Sociology and Anthropology, Ben Gurion

University, Beersheba, Israel

e-mail: aviadraz@bgu.ac.il

C. Shalev

Maria-Goeppert-Mayer guest professorship in 2008, University Medical Center Göttingen, Göttingen, Germany e-mail: cshalev@012.net.il euthanasia and advance directives, and conclude with a comment on the difficulty in classifying either stance as more or less restrictive.

Keywords Culture End of life $\cdot$ Expert ethics committees · Doctors' duties · German law · Living will · Israeli Law · Patients' rights · Religion

\section{Introduction}

End-of-life (EoL) decisions concerning passive and active euthanasia, or the handling of advance directives, are very complex and closely linked to legal, medical, religious, and bioethical discourses. In this paper ${ }^{1}$ we examine and deconstruct these linkages in Germany and Israel, moving beyond one-dimensional constructions of ethical statements as "social facts" to their conflicting and multi-faceted embedding within professional, religious, and cultural perspectives (Turner 2005).

Germany and Israel, both at the cutting edge of Western medical progress, constitute opposing examples of professional culture in relation to biomedicine-especially in all questions pertaining to reproductive and genetic technologies at the beginning of life. So far, bioethical comparisons between Germany and Israel have generally shown Germany to be more restrictive and Israel to be more

\footnotetext{
$\overline{1}$ This paper is a very condensed but slightly revised version of a more extensive comparative Germany-Israel analysis of EoL ethics, published as: S. Schicktanz, A. Raz and C. Shalev, The Cultural Context of End-of-LifeEthics: A Comparison of Germany and Israel, 19 Cambridge Quarterly of Healthcare Ethics (2010)381-394. In this paper, a new focus is on advance directives.
} 
permissive. Various studies have shown that German and Israeli professionals such as genetic counsellors, bioethicists and physicians differ strongly in their moral assessment of various biomedical issues including preimplantation and prenatal genetic diagnosis, stem cell research and issues of selective abortion (Wertz and Fletcher 1989; Hashiloni-Dolev 2007; Gottweis and Prainsack 2006). While all these studies have dealt with the beginning of life, in this article we consider the other side of the life-span, namely EoL decisions. We want to explore whether the same moral opposition also characterizes EoL ethics in the two countries.

The juxtaposition of Germany and Israel highlights the context of cultural variation and pluralism in the moral assessment and evaluation of EoL dilemmas. We focus mainly on the variation in experts' roles and physicians' duties, as well as on the role of religion and the historical factor of the Holocaust. The descriptive part of this study presents an ethical analysis of the statements of two national expert committees on EoL in Israel and Germany. This analysis leads us to discuss the notion of restrictive versus permissive bioethics, further embedding it in the cultural context of assimilating medico-technical developments.

\section{Methods}

Our bi-national analysis of the EoL ethics discourse focuses on the official statements of two national expert committees in Israel and Germany. We analysed these statements with a special focus on passive euthanasia and advance directives (see for more details: Schicktanz et al. 2010) along the following research questions: (A) What are the main ethical principles mentioned? (B) What are the main problems identified? (C) What role do cultural and historical factors play? By deconstructing each of the statements and exposing their basic elements, which were then compared cross-culturally, this methodology aimed at uncovering the embedding of ethics within multi-faceted and conflicting cultural narratives. In such manner we offer a subversive analysis of ethical declarations as presenting an illusion of being monolithic and consensual 'social facts' (Haimes and Williams 2007).

We compare the Israeli Report of the Public Committee on "The Care of Dying Patients" (2002) (the so called Steinberg-Committee), ${ }^{2}$ with the 2006 German National Ethics Council (NEC) Opinion Report on "Self-determination and Care at the End of Life" (in the following

\footnotetext{
${ }^{2}$ See an English translation published in Hurwitz et al. (2006).
}

abbreviated as GE-Opinion-EoL), and the 2005 German National Ethics Council's Opinion Report on "Advance directives (abbreviated as GE-Opinion-AD). ${ }^{3}$ These two national ethics committees were both found in a politically powerful position. For the purpose of ethical analysis we focus primarily on the original and full statement of the respective committee, rather than on the latest version of the law itself (although we refer also to the updated legal situation), since the committees' statements contain the discussion of the premises and arguments underlying the formulation of the law (see also Lepping 2007). A new German law (from 1/9/09) (German Civil Code §1901a Living wills as part of $\S 1901$ 'Scope of custodianship/ duties of custodianship') proclaims, as recommended by the NEC (see below), that existing advance directives are binding on attending physicians and strengthen the role of proxies in EoL decisions. A rather short, but very controversial parliamentary debate preceded this regulation. In Israel, the Knesset enacted the Dying Patient Law in 2005, based on the recommendations of the expert committee report, which also addressed advance directives and proxy decision-makers. However, in both countries many practical questions concerning the implementation of the laws are still debated.

The German National Ethics Council was appointed by the German Chancellor in 2001 with the general mandate to discuss urgent bioethical issues and to advise the Chancellor, the parliament and the public. The Israeli committee was appointed by the Minister of Health in 2000, following a Supreme Court judgment calling for legislation to clarify the matter of advance care planning, with the specific mandate to formulate a comprehensive legislative proposal on EoL medical care. Both committees were comprised of an interdisciplinary membership. At the time of its EoL report, the German Committee consisted of 25 members (professional philosophers, lawyers, medical scientists, patient representatives, politicians and Catholic and Protestant religious authorities) and chaired by the lawyer and politician Christiane Weber-Hassemer. The Israeli Committee consisted of 59 expert members, making it the largest public committee ever established in Israel, and was chaired by the paediatric neurologist and halakhicmedical ethicist Avraham Steinberg (2006, p. 100). Both national committees aimed for a formal consensus statement which was achieved in the main part, but both also offer some dissenting statements.

\footnotetext{
${ }^{3}$ English translation published by the German NEC is available at http://www.nationalerethikrat.de/en_index.php.
} 


\section{Comparative analysis of the statements}

\section{Legal backgrounds}

In both countries, to the date of the reports no specific EoL law existed. In Israel, there were Ministry of Health guidelines (1996) and several court decisions that indicated recognition of certain legal principles (e.g., the patient's right to refuse treatment, the prohibition of active euthanasia, in dubio pro vitae) within the general frame of the Patient's Rights Law (1996) (Shalev 2000). However, there was a lack of clarity as to the distinction between passive and active euthanasia, and as to the effect of advance directives. In Germany, there existed sections in the criminal law which were relevant to EoL decisions, as well as articles in the Constitution, such as Article 2(1), which protects the right to free personal development, and Article 2(2), which protects the individual's right to life and physical integrity and had been construed to include autonomous decisions in shaping the dying process. However, there remained considerable legal questions about the doctor's position as a guarantor of life, and a large degree of ambivalence as regards the doctor's duties.

\section{Main similarities and differences}

The main recommendations in both expert committee statements can be summarized with respect to their similar articulation of the following five points:

- There is a duty to administer palliative care.

- There is a duty to administer basic care, which includes hygiene, social care, and treatment to assuage feelings of starving and of thirst.

- Killing on request (so-called active euthanasia) should be legally forbidden. Both statements proclaim that no doctors or other persons should be allowed to kill a patient (e.g. by applying a deadly dose of a substance), even on the patient's explicit wish.

- In case of doubt or uncertainty about the patient's wish, a decision in favor of life ought to be made: In the absence of an explicit statement or advance directive by the patient, and if the relatives seem to be unclear or contradictory as to the patient's presumed wishes, physicians and care givers should save life and not stop life sustaining care.

- The role of advance directives has to be strengthened and made legally binding.

At the same time, the two reports differ in some major respects. The first discrepancy concerns the moral acceptance of 'letting die' (a term suggested by the German NEC to be used for 'passive euthanasia'). In the German report a strong consensus was expressed that 'letting die' encompasses both withholding and withdrawing medical treatment, and the NEC supported it so long as it is in accordance with the patient's explicit wish. In contrast, the Israeli report stood out from most international reports and laws by stressing the significance of the distinction between interrupting (withdrawing) and refraining from (withholding) medical treatment, because of psychological, philosophical and religious (halakhic) reasons associated with the former. Hence, the Steinberg Committee report concluded that withholding or refraining from medical treatment is morally acceptable if in accordance with the patient's explicit voiced wish; however, withdrawing or interrupting continuous treatment such as artificial respiration or artificial feeding is seen as morally unacceptable even if the patient so wishes (see the more detailed discussion below).

The emerging role of advance directives

With respect to advance directives, the Israeli report stressed the need to acknowledge the effect of advance directives made by individuals after receiving relevant medical information from medical caregivers, and recommended that a national registry be established to facilitate their actual implementation. The subsequent law contains official statutory forms that include lists of multiple-choice questions representing, for example, various specific techniques of resuscitation, distinctions between 'dying' and 'terminal' patients, 'treatment related to the 'incurable medical problem' and 'accompanying treatment', and 'continuous' versus 'cyclical' treatment. They thus appear to reduce the complex communication of EoL decisions to a long list of medical procedures and formal legal language that, arguably, alienates lay persons and makes them dependent on lawyers and doctors, instead of empowering them to make their own choices in their own words (Shalev 2009, 2010).

In Germany, the NEC recommended making advance directives legally binding for physicians, care givers and legal representatives (GE-Opinion-AD), but did not address the practical problem of implementing advance directives in medical practice. The recent German law was the result of a heated parliamentary debate in which at least four different motions were discussed. The law gives legal effect to advance directives while other issues of EoL decisions are not explicitly regulated. Furthermore, the law stresses the role of proxies which should ensure that doctors are following the patient's wishes as expressed in the AD: Hence, ADs have to be written documents, but neither a doctor's information nor a notarial act is required. No national registry for $\mathrm{AD}$ is foreseen. While the advance directive form issued by the German Federal Ministry of Justice is similarly loaded with medico-legal jargon, there 
are many other forms for advance directives in Germany, including those issued by the churches and by patient support organizations, which range in style from the formal to the informal. Nonetheless, only very few Germans have an advance directive. ${ }^{4}$

\section{Cultural diversity of moral key elements}

Balancing various, sometime opposing values seems to be the key element in EoL decisions, according to both committees' statements. Value balancing entails a twofold problem: First, one has to justify the main ethical principles; secondly, some hierarchy between the principles has to be considered. In the Israeli report, four main ethical principles were mentioned: sanctity of life, prevention of significant suffering, quality of life, and patient autonomy. On the other hand, the German report referred to selfdetermination and protecting bodily integrity as part of patient autonomy, then to protection of life, and solidarity with vulnerable persons.

The place of patient autonomy in the order of the ethical principles seems to be of significance, as well as the German report reference to 'protection of life', as opposed to 'sanctity of life', which has a less religious and less absolute connotation. Indeed, the German committee understood the right of self-determination to be "the" ethos of contemporary life. In contrast, the Israeli report started with a general presumption that autonomy, as "a" democratic value, has to be balanced with Jewish religious values - of which 'sanctity of life' is the most important. This can be seen in the (non-liberal, socially prescriptive) recommendation of the Israeli committee that caregivers have a duty to persuade patients to accept oxygen, food, drink and regular medicine, and that they may not withdraw ongoing medical treatment (Steinberg-Report 2006, p. 221). Similarly, the Israeli law adopted the committee's recommendation that doctors must administer artificial feeding and fluids even if the patient made advance directives to the contrary.

\section{Handling conflicts in EoL situations}

The role of experts represents a key element in both committees. The Israeli report delegated the responsibility for conflict resolution to medical and health care experts, and the Dying Patient Law established institutional ethics expert committees with the power to make decisions if

\footnotetext{
4 According to several studies the numbers vary between $10-20 \%$. (e.g. Lang and Wagner 2007; Justinger et al. 2009).
}

there is a conflict between the involved parties. These committees must take into account the patient's wishes according to his/her world view and life-style (see also: Steinberg Report 2006, p. 232). But in the case of unresolved dissent in the institutional ethics committee, a national committee is authorized to decide.

Concerning the same issue, a debate developed in the German committee. Its general report on EoL care remained imprecise regarding who should decide in a situation of conflict: the physician, the patient, or the state; yet the answer can be found in the earlier report on advance directives: "in the event of conflict-in particular concerning the interpretation of the advance directive-the Court of Guardianship should decide." (GE-Opinion-AD, p. 57). The recent law took up this approach by providing that the Court of Guardianship has jurisdiction to make decisions when there are conflicts between physician and proxy with regard to life-shortening decisions.

The cultural assessment of experts' responsibility is hence quite different: While in Israel health care experts are seen as best equipped to solve EoL dilemmas, in Germany the power to do so is put in the hands of legal experts. This is reflected also in the expertise of the two heads of the respective committees: in Germany, a lawyerphilosopher; in Israel a physician-cleric.

\section{Passive euthanasia}

The debate on the morality of active and passive euthanasia, or the distinction between withholding and withdrawing treatment, (passive and active "letting die") was a matter of fierce controversy in the international bioethics community, especially until the mid-1990s (see Callahan 1989; Nordcross and Steinbock 1994; overview by Howard-Snyder 2007). Nowadays, however, most international statements agree that there is no substantial moral or legal distinction between withholding and withdrawing, because of consequentialist and intentional considerations. Correspondingly, the German Report emphasized that there is no morally relevant distinction between the cessation of a continuing medical treatment as opposed to not administering it in the first place (GEOpinion-EoL, p. 46). The examples mentioned are artificial feeding and respiration. The report concluded that the morally relevant action is to omit an unwanted treatment (p. 47), although it acknowledged that it is "psychologically understandable if the doctor ... is more reluctant to intervene actively_by removing a feeding tube or turning off a respirator-than simply do nothing." (ibid. p. 47).

It concluded that in both cases the intention (stopping an unwanted treatment) and the outcome (death) of the action are what count morally. Therefore, the distinction between 
actively doing and omitting was seen as inherently unjustified from a moral point of view. ${ }^{5}$

In contrast, the moral distinction between withholding and withdrawing treatment played an important role in the Israeli report. The argument for such a distinction is explained by the Chair Steinberg (2006, p. 103): "According to relevant halakhic principles and the actual rulings of these prominent rabbis, preserving life is one of the most important values. Any act that shortens life is halakhically considered as murder, even at the very end of life (...). Therefore, active euthanasia, physician-assisted suicide or the withdrawal of a continuous treatment such as a pacemaker or a respirator is absolutely forbidden" (emphasis added).

However, this position was criticised by various (secular) ethicists and lawyers in the Israeli committee as unethical, and inconsistent with the previous case law. Judges, legal scholars and philosophers maintained that there was no logical difference between withholding and withdrawing treatment, in accordance with the international agreement. From a patient rights perspective, it was argued that just as informed consent is required before the administration of medical treatment, so too treatment may not be continued against the will of the patient, since in both cases the forced treatment is a violation of the right to bodily integrity and amounts technically to assault. Moreover, a rule forbidding the withdrawal of "continuous" treatment at the patient's request might be detrimental, because it could induce a patient to forgo potentially beneficial treatment out of fear that once it is begun it cannot be stopped. In addition, artificial respiration is often initiated as a matter of course in conditions of medical emergency, where the patient does not have a real option to indicate consent due to the circumstances. The rule of first treating and then asking questions in emergencies is entirely appropriate, but if discontinuation of treatment is not allowed, patients can find themselves held captive by life-prolonging measures which they might have preferred to refuse. (Shalev 2009).

The Steinberg Committee proposed a technological solution, in order to ameliorate its position that withdrawal of treatment should not be permitted, and to reach a consensus between the secular and religious camps of the committee. It invoked a novel distinction between 'continuous' and 'discontinuous/serial' treatment, based on the idea that medical treatment can be seen as one "act" or as a sequence of acts. For example, the administration of dialysis is seen as a sequence of single, equivalent acts, while artificial respiration over several months is seen as only one act. However, if a timer would be installed on a respiratory machine, so that it automatically switches off the respirator

\footnotetext{
5 The very recent decision of the German Federal Court of Justice confirmed this view (no. 129/10 on 25th June 2010).
}

after a set period of time and has to be intentionally turned on by someone again, the treatment would then be considered as discontinuous. The resetting of the clock would be routine care unless the patient explicitly expresses her wish not to turn it on again.

At the same time, some critics questioned the merit of this idea. Such a technology may be very useful for overcoming the understandable reluctance of a doctor to "pull the plug," but it raises various questions. For example, if it is morally wrong to discontinue life support, what difference does it make how we perform the act? Can a change of technique make right of something that is wrong? (Ravitsky 2006).

\section{Historical factors}

In the German EoL debate, the spectre of the "Nazi doctors" played a significant argumentative role (see for example Schmuhl 2000; Ach and Gaidt 2000; Kröner 2001). Because of this, there are still special sensitivities around the use of the term 'euthanasia' in Germany and therefore the German NEC introduced the term 'criminal euthanasia' (2006) to distinguish the murders of disabled persons during Nazi times as a separate category under the more general label of 'euthanasia'. In the Israeli debate, the term of 'mercy killing' does not carry the same sensitivity.

Similar historical considerations came up in the German NEC, when its members discussed the ethical and social dimensions of killing on request (active euthanasia). Those members of the NEC who considered it to be ethically acceptable in principle (GE-Opinion-EoL p. 86f) nevertheless supported the recommendation that it should be legally forbidden because of political considerations. These considerations might be interpreted as taking historical responsibility for criminal euthanasia practiced under the Nazi regime - an argument explicitly mentioned by members of the NEC. In the Israeli report we cannot find any comparable expression or reference.

\section{Religious factors}

The Israeli view on EoL care appears to be restrictive in contrast to its general permissiveness on reproductive and genetic issues at the beginning of life. This contrast between the beginning and end of life could be explained by the 'two-fold' view of Israeli society (Raz 2004). In Israel the perception is that there is a gradual development of moral status from the pre-born (partial moral status of the embryo) to the already-born (full moral status), while in Germany full moral status is already attributed to the human embryo from the moment of conception. These different perspectives reflect the variance between religious views in Judaism and Christianity. 
The Israeli position is sometimes explained by the fact that 'sanctity of life' is seen as the highest religious (Jewish) ethical principle (Glick 1999; Green 1999; Ganz et al. 2006; Rosner 1999). Interestingly, Jewish ethics scholars such as Leonard Kravitz (2006) claim that the statements in the Steinberg committee's report do not present any universalistic position of Jewish thinking (especially with respect to the proscription of withdrawing treatment)

In the German debate, too, the religious impact should not be underestimated. Christian authorities refer similarly to the sanctity of life and the moral unacceptability of terminating human life, seen as a gift from God (GEOpinion-EoL p. 75). However, the religious position is presented as one voice among many others, in a concert of pluralistic discourse. National surveys overall showed that a majority of the German population is actually in favour of active euthanasia (GE-opinion-EOL 2006). Future studies could examine if the German objection to active euthanasia, as expressed by politicians as well as most experts, is due to continuing loyalties to the two Christian churches. ${ }^{6}$

\section{Conclusions}

In contrast to its general permissiveness in the beginningof-life discourse, the Israeli view on EoL appears to be much more restrictive than the German view. The Israeli stance concerning passive euthanasia seems more restrictive because of three reasons: (a) doctors must persuade patients to accept life-supporting medical treatment; (b) doctors may not respect a competent patient's expressed wishes to withdraw continuous life-supporting treatment, and (c) doctors may not respect an incompetent patient's advance directives to withhold artificial feeding.

Thus the contrast between German and Israeli perspectives of EoL care can be seen to represent different social conceptions of the doctor's duty vis-à-vis the balancing of the sanctity of life versus individual self-determination. The German emphasis is on the doctors' duty to respect the patient's autonomy, while the Israeli focus is on the doctors' duty to respect the sanctity of life.

But we would like to refine our own generalization by offering a more differentiated understanding of the term "restrictive." Considering Israel's practical solution of the timer, one could ask whether this is still considered "restrictive". The answer to that question depends inter alia on who will have the power to decide whether the timer is set up again - the patient (Barilan 2004) or the physicians and caregivers (as the committee has suggested). And although the technical solution of the timer

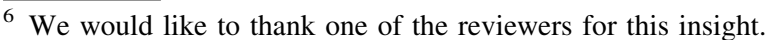

was regarded by some authors as a fig leaf for a moral conundrum or even a 'sell-out' (Butcher 2005; Ravitsky 2005), one could see it instead as a pragmatic way out of a value-laden conflict that enables individual solutions. In terms of Israeli culture, such pragmatism has been shown to serve as a main cultural interface between Jewish tradition and secular modernism (Gross and Ravitsky 2003; Shapira 2006).

The taken-for-granted German predilection for protecting individual autonomy should be reviewed in light of the German debate on advance directives. While the Steinberg committee recommended increasing the relevance and binding character of advance directives, the call of the German NEC in favour of strengthening advance directives was criticized by other interdisciplinary ethics committees, such as the German Interim Parliament Commission for Ethics and Law of Modern Medicine (Enquete-Komission 2002). Likewise, the recent German legal solution of delegating decisions to judges in cases of conflicts between proxies and doctors can be interpreted as (partly) restricting patients' autonomy. These nuances illustrate how the German EoL legal policy is also restrictive in certain respects, just as the Israeli EoL law also has some permissive aspects.

Acknowledgments Silke Schicktanz would like to thank the German Israeli Foundation-Young Scientist Programme GIF research Grant No. G-21071451-4/2005 for supporting her research.

\section{Conflict of interests None.}

Open Access This article is distributed under the terms of the Creative Commons Attribution Noncommercial License which permits any noncommercial use, distribution, and reproduction in any medium, provided the original author(s) and source are credited.

\section{References}

Ach, J.S., and A. Gaidt. 2000. Wehret den Anfängen? Anmerkungen zum Argument der 'schiefen Ebene' in der gegenwärtigen Euthanasie-Debatte. In Euthanasie und die aktuelle SterbehilfeDebatte. Die historischen Hintergründe medizinischer Ethik, ed. A. Frewer, and C. Eickhoff, 424-447. Campus: Frankfurt a. M.

Barilan, M.Y. 2004. Is the clock ticking for terminally ill patients in Israel? Preliminary comment on a proposal for a bill of rights for the terminally ill. Journal for Medical Ethics 30: 353-357.

Butcher, T. 2005. Israelis to be allowed euthanasia by machine. Telegraph.co.uk, London. 12th Aug.

Callahan, D. 1989. Can we return death to disease. The hastings center report. 19 (Jan/Feb), 4-6.

Enquete Kommission. 2002. Law and ethics of modern medicine Final Report. Berlin: German Parliament (in German).

Ganz, F., J. Benbenishty, et al. 2006. The impact of regional culture on intensive care end of life decision making: An Israeli perspective from the ETHICUS study. Journal for Medical Ethics 32: 196-199.

Glick, S. 1999. The Jewish approach to living and dying. In Jewish and catholic bioethics. An ecumenical dialogue, ed. E.D. 
Pellegrino, and A.I. Faden, 43-53. Washington: Georgetown University Press.

Gottweis, H., and B. Prainsack. 2006. Emotion in political discourse: Contrasting approaches to stem cell governance: the US, UK, Israel, and Germany. Regenerative Medicine 1: 823-829.

Green, R.M. 1999. Jewish teaching on the sanctity and quality of life. In Jewish and catholic bioethics. An ecumenical dialogue, ed. E.D. Pellegrino, and A.I. Faden, 25-42. Washington: Georgetown University Press.

Gross, M.L., and V. Ravitsky. 2003. Israel: Bioethics in a Jewishdemocratic state. Cambridge Quarterly of Healthcare Ethics 12: $3247-3255$.

Haimes, E., and R. Williams. 2007. Sociology, ethics, and the priority of the particular: Learning from a case study of genetic deliberations. British Journal of Sociology 58(3): 457-476.

Hashiloni-Dolev, Y. 2007. A life (un)worthy of living: Reproductive genetics in Israel and Germany. Berlin: Springer.

Howard-Snyder, F. 2007. Doing vs. allowing harm, Stanford Encyclopedia of Philosophy http://plato.stanford.edu/entries/doingallowing/(accessed 26 05.2010).

Hurwitz, P., J. Picard, and A. Steinberg (eds.). 2006. Jewish ethics and the care of end of life patients. A collection of rabbinical, bioethical, philosophical and juristic opinions. Basel: Schwabe.

Justinger, C., S. Richter, M.R. Moussavian, T. Serrano Contreras, and M.K. Schi. 2009. Patientenverfügung aus der Sicht des chirurgischen Patienten. Der Chirurg 80(5): 455-461.

Kravitz, L.S. 2006. Some reflections on Jewish tradition and the endof-life patient. In Jewish ethics and the care of end-of-life patients. A collection of rabbinical, bioethical, philosophical, and juristic opinions, ed. P.J. Hurwitz, J. Picard, and A. Steinberg, 75-98. Jersey City: KTAV Publishing House.

Kröner, H.-P. 2001. 'Euthanasie': Von der Sterbebegleitung zum Krankenmord. In Tod und Sterben: Medizinische Perspektiven, ed. P. Hucklenbroich, and P. Gelhaus, 87-103. Münster: LIT.

Lang, F.R. and G.G. Wagner. 2007. Patientenverfügungen in Deutschland: Bedingungen für ihre Verbreitung und Gründe der Ablehnung. Deutsche Medizinische Wochenschrift 132(48): 2558-2562.

Lepping, P. 2007. Ethical analysis of the new proposed mental health legislation in England and Wales. Philosophy, Ethics, and Humanities in Medicine 2: 5.

National Ethics Council. 2005. Opinion report on advance directives. Berlin. (Abbr. GE-Opinion-AD).

National Ethics Council. 2006. Opinion Report on self-determination and care at the end of life. Berlin (Abbr. GE-Opinion-EoL).

Nordcross, A., and B. Steinbock. 1994. Killing and letting die, 2nd ed. New York: Fordham University Press.

Public Committee on Matters concerning the Terminally Ill Patients. 2006. Draft Law, Report, and divergent opinions. In: Hurwitz
P.J., Picard, J., and Steinberg A. (eds.) Jewish ethics and the care of end-of-life patients, Jersey City: KTAV Publishing House, pp. 207-242 (Abbr Steinberg -Report).

Ravitsky, V. 2005. Timers on ventilators. British Medical Journal 330: 415-417.

Ravitsky, V. 2006. Dying with dignity in a Jewish-democratic state. In Jewish ethics and the care of end-of-life patients. A collection of rabbinical, bioethical, philosophical, and juristic opinions, ed. P.J. Hurwitz, J. Picard, and A. Steinberg, 105-118. Jersey City: KTAV Publishing House.

Raz, A. 2004. 'Important to test, important to support': Attitudes toward disability rights and prenatal diagnosis among leaders of support groups for genetic disorders in Israel. Social Science and Medicine 59(9): 1857-1866.

Rosner, F. 1999. The imperative to heal in traditional judaism. In Jewish and catholic bioethics. An ecumenical dialogue, ed. E.D. Pellegrino, and A.I. Faden, 99-105. Washington: Georgetown University Press.

Schicktanz, S., A. Raz, and C. Shalev. 2010. The cultural context of end-of-life ethics: A comparison of Germany and Israel. Cambridge Quarterly of Healthcare Ethics 19: 381-394.

Schmuhl, H.-W. 2000. Nationalsozialismus als argument im aktuellen Medizinethik-Diskurs. Eine Zwischenbilanz. In Euthanasie und die aktuelle Sterbehilfe-Debatte. Die historischen Hintergründe medizinischer Ethik, ed. A. Frewer, and C. Eickhoff, 385-407. Campus: Frankfurt a. M.

Shalev, C. 2000. Paternalism and autonomy in end-of-life decisionmaking: the Israeli normative ambivalence. Israel Yearbook on Human Rights 29: 121-136.

Shalev, C. 2009. End-of-life care in Israel-the dying patient law 2005. Israel Law Review 42(2): 279-305.

Shalev, C. 2010. Reclaiming the patient's voice and spirit in dying: A perspective from Israel. Bioethics 24(3): 133-144.

Shapira, A. 2006. Law and bioethics in Israel: Between liberal ethical values and Jewish religious norms. Journal International de Bioéthique 7(1-2): 115-123.

Steinberg, A. 2006. A law proposal in Israel regarding the patient at the end of life. In Jewish ethics and the care of end-of-life patients. A collection of rabbinical, bioethical, philosophical, and juristic opinions, ed. P.J. Hurwitz, J. Picard, and A. Steinberg, 99-104. Jersey City: KTAV Publishing House.

Turner, L. 2005. From the local to the global. Bioethics and the concept of culture. Journal of Medicine and Philosophy 30: 305-320.

Wertz, D.C., and J.C. Fletcher (eds.). 1989. Ethics and human genetics: A cross cultural perspective. Berlin: Springer. 